\title{
3. MRIの技術的諸問題
}

藤田学園 保健衛生大学病院 㳄田武司]

現在、私共が使用致して居ますＭＲＩ装置は、島津製 S M T - 150 である。本装置は昭和62 年 9 月 20 日に搬入・設置して以来、約 3 ケ月間の調整後昭和 62 年 12 月 10 日より臨床検查 を開始しました。以後昭和 63 年 11 月 10 日現在で患者数は約 930 件に達しました。乙こに、 本装置の使用経験を基にして、M R I の問題点を述べる。1）初めに、S M T - 150の漏洩磁 場を計测した。本䒾置はself shield type のために、この効果を確琵するためにgauss meter を用いて、空間漏洩磁場分布を計測した。忺に、2）装置の性能評価の1つとして、スライス厚 について検討した。MRIの特色はスライス載面が多方向より任意に撮像出来ることにある。こ の時に、スライス厚がどの様に変化するかは興味があり、ファントムで計測比較した。更に、 3) 腹部M R I の撮像シーケンスについて、腹部M R I 者検查する際、体動による artifact 問題になる。このために、matrix 数、加算回数を考虑して、出来るかぎり撮像時間を短縮すへ さシーケンスを選択した。他方、4）高速スキャンStage法における flip angle と信号強度に ついて調べた。その他1.5 Tにおける M R I 造影剤 G d - D T P A を用いた時の希釈濃度と $\mathrm{T}_{1}$

- $\mathrm{T}_{2}$ 值の関係を検討した結果も報告致します。

\section{3次元撮影と画像表示法の臨床応用について}

東芝メディカルエンジニアリング侏）橿田淳一

[はしめに]

3次元フーリエ变换法（3DFT法）は、2次元フーリエ変换法 (2 DFT法)にスライス方间の エンコードが加わるため、揪影に要する時间が長く実用にならなかった。現在、楳り返し時间TR数 十ミリ秒のクラジエントフィールトエコー法（FE法）を角い、3 D F Tの掫影時间も十数分程度ま で短維されている。得られた画像は、通常のマルチスライス像としての表示の他、さらに真の3次元 テータとしての情報を十分に生かせるような表示法も模討した。

[方法]

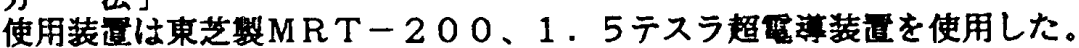

3 D F T Thin slice法 マトリックス $256 \times 256 \times 32$

3DF TVolume scan 法 ボクセルサイス $1.0 \times 1.0 \times 1.5$ (又は 1.0 ) マトリックス $128 \times 128 \times 128$ ボクセルサイス 2.0 $0 \times 2.0 \times 2.0$

にて3次元デー夕収集を行う。

3次元画像表示法として

を試みた。

1. 高速断面变换法

4.アニメーション表示法

2. 表面表示法

5. 再投影法

3. 1 と 2 の合成表示法

[桔果]

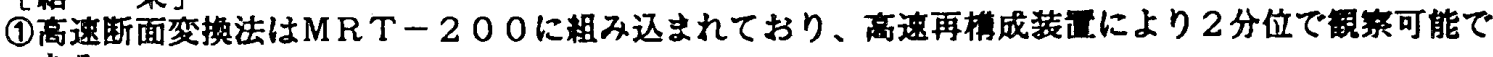
ある。

(2)等方的な3D F Tデータにて閴面及び䐻面の表示を作成した。

(3)断面変换法と表面表示法を粗み合せて表示した。

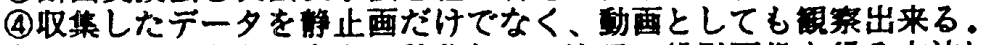

(5) 3次元画像をある方向に程分し、2 㳄元の投影画像を得る方法は、血管系の表示法として有用であ つた。

[まとめ]

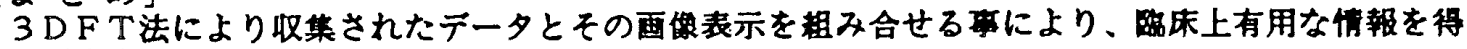
る事が出来る。 